\title{
ARTIGOS
}

\section{O URBANISMO COMO ECONOMIA POLIITICA DO/NO ESPAÇO: REFLEXÕES A PARTIR DO PROCESSO DE METROPOLIZAÇÃO DE BELO HORIZONTE ${ }^{1}$}

Thiago Andrade dos Santos ${ }^{2}$

Universidade Federal de Minas Gerais

\section{Enviado em 10 mar. 2017 | Aceito em 17 mai. 2021}

Resumo: Este estudo discute o processo de produção do espaço de Belo Horizonte, tendo como fio condutor a análise da ação conjunta entre Estado e capital. Mostra-se, a partir do caso prático de Belo Horizonte, que, no processo de modernização e metropolização contemporâneos, a espoliação dos mais pobres continua a ocorrer. Nesse processo, o urbanismo, travestido de planejamento urbano e regional, planejamento estratégico etc., assume seu papel de saber político vinculado às necessidades do capital, organizando o espaço em função dos interesses deste último. A valorização do solo urbano acontece com o auxílio das intervenções do Estado via instrumentos de planejamento urbano previstos na própria legislação urbanística brasileira. Há a elevação do preço da terra e dos serviços, o que tende a dificultar o acesso dos trabalhadores de baixa renda, sendo a renda fundiária oriunda desses processos apropriada pelo capital rentista. Considerando as características da urbanização na porção norte da Região Metropolitana de Belo Horizonte no passado em comparação com o momento atual, verifica-se que, embora o capitalismo venha se trasformando ao longo do último século, se adaptando às suas crises, a sua essência permanece a mesma, bem como a essência da urbanização que produz. Observa-se como desdobramento direto uma nova rodada de gentrificação do espaço e do consequente processo de periferização por conta da ampliação da capitalização do solo urbano da metrópole.

Palavras-chave: Urbanização; Produção do Espaço; Capital; Estado; Urbanismo.

\section{URBANISM LIKE POLITICAL ECONOMY OF THE/IN THE SPACE: REFLECTIONS BASED ON THE BELO HORIZONTE METROPOLIZATION PROCESS CASE}

Abstract: This study discusses the Belo Horizonte's production of space process, having as a guideline the analysis of the association between government and capital. It is shown from the empirical case of Belo Horizonte that in the contemporary modernization and metropolization process the dispossession of the poorest continues. In this process, urbanism, disguised of urban and regional planning, strategic planning, etc., assumes its role of political knowledge linked to organize the space in function of the capital needs. The valorization of urban soil occurs with the aid of State interventions using urban planning instruments provided for in the Brazilian urban legislation itself. There is an increase in the price of land and services, which tends to hinder the access of low-income workers, and the land income from these processes is appropriated by rentier capital. Considering the characteristics of urbanization in the northern portion of the Metropolitan Region of Belo Horizonte in the past compared to the current moment, it appears that, although capitalism has been changing over the last century, adapting to its crises, its essence remains the same, as well as the essence of the urbanization it produces. A new round of gentrification of the space and the consequent process of periphery growth can be observed as a direct development due to the expansion of the capitalization of metropolis urban land.

Keywords: Urbanization; Production of Space; Capital; State; Urbanism.

\section{EL URBANISMO COMO ECONOMÍA POLÍTICA DEL / EN EL ESPACIO: REFLEXIONES A PARTIR DEL PROCESO DE METROPOLIZACIÓN DE BELO HORIZONTE}

Resumen: Este estudio discute el proceso de producción del espacio de Belo Horizonte, teniendo como pauta el análisis de la acción conjunta entre Estado y capital. Se muestra, a partir del caso práctico de Belo Horizonte, que, en el proceso de modernización y metropolización contemporánea, se sigue produciendo el saqueo de los más pobres. En este proceso, el urbanismo, disfrazado de

1 Este estudo é parte integrante da dissertação de mestrado do autor, defendida em novembro de 2014, sendo incorporados outros conhecimentos adquiridos nesse intervalo entre a defesa e a submissão desse material na forma de artigo.

2. Doutor em Geografia pela Universidade Federal de Minas Gerais. ORCID: https://orcid.org/0000-0002-3438-7456 E-mail: thiago_andsant@yahoo.com.br.

*Agradeço à CAPES pelo financiamento desta pesquisa por meio de uma bolsa de estudos. 
planificación urbana y regional, planificación estratégica, etc., asume su papel de conocimiento político vinculado a las necesidades del capital, organizando el espacio según los intereses de este último. La valorización del suelo urbano se da con la ayuda de intervenciones estatales mediante los instrumentos de planificación urbana previstos en la propia legislación urbana brasileña. Existe un aumento en el precio de la tierra y los servicios, lo que tiende a dificultar el acceso de los trabajadores de bajos ingresos, y los ingres os de la tierra de estos procesos son apropiados por el capital rentista. Considerando las características de la urbanización en la parte norte de la Región Metropolitana de Belo Horizonte en el pasado en comparación con el momento actual, parece que, aunque el capitalismo ha ido cambiando durante el último siglo, adaptándose a sus crisis, su esencia sigue siendo la misma, así como la esencia de la urbanización que produce. Una nueva ronda de gentrificación del espacio y el consecuente proceso de periferización puede verse como un desarrollo directo debido a la expansión de la capitalización del suelo urbano de la metrópoli.

Palabras-clave: Urbanización; Producción espacial; Capital; Estado; Urbanismo.

Introdução

Este estudo tem como objetivo analisar os movimentos do processo de produção do espaço de Belo Horizonte, especialmente da porção norte de sua região metropolitana. Objetiva-se mostrar as "novas" tramas urbanas criadas com a passagem de uma urbanização guiada pelas indústrias para essa guiada também pelos capitais rentistas e financeiros. O "fio condutor" desta exposição é a análise da ação conjunta entre Estado e capital em crise na organização e na produção do espaço. Tal empreitada foi levada a cabo pela análise do processo de modernização e metropolização de Belo Horizonte, articulando-os às tentativas de resposta às crises estruturais de valorização dos capitais.

O capital somente sobrevive produzindo espaços e o crescimento do tecido urbano é a materialização desse processo. Nesse contexto, a gentrificação do espaço e a exclusão dos mais pobres surgem como desdobramentos diretos. Ademais, o urbanismo, travestido de planejamento urbano e regional ou planejamento estratégico, assume seu papel de saber político vinculado às necessidades das classes dominantes de organizar o espaço em função dos seus interesses (MARTINS, 2000, p. 54). O urbanismo aparece "como o veículo de uma racionalidade limitada e tendenciosa da qual o espaço, ilusoriamente neutro e não-político, constitui o objeto (objetivo) (LEFEBVRE, 1999, p. 150).

Em um capitalismo atuante na escala global, todo espaço social entra nas tramas reprodutivas do capital, sendo o entendimento de sua produção tão importante quanto o estudo das relações de produção que acontecem nele (LEFEBVRE, 2016, p. 48-49). A abordagem de Lefebvre (1991, p. 299) propõe que, nas análises acerca da prática social, seja incorporada à crítica da "economia política das coisas no espaço" a crítica da "economia política do espaço e de sua produção", pois a primeira sozinha deixa em segundo plano o fato de o espaço assumir uma complexa e estratégica função dentro das tramas reprodutivas do capital. Essa acepção revela que o espaço contém as mercadorias produzidas e sua organização e estruturação incidem diretamente nos lucros das empresas. Ademais, o próprio espaço tornou-se uma valiosa mercadoria a ser comercializada e, também, o objeto de lutas sociais de diversas naturezas.

Dessa maneira, o que presente texto vai mostrar, a partir do caso particular da metropolização de Belo Horizonte, é a impossibilidade de o processo global de reprodução do capital se realizar sem contradições e sem o auxílio do Estado em suas diversas escalas de atuação. Para se valorizar, o capital tem que se apropriar de tudo e de todos, inclusive do espaço, e isso produz contradições como o fato de o cidadão não poder se apropriar plenamente da vida nas cidades para exercer uma cidadania plena. Pois, ora, se o espaço é socialmente produzido (LEFEBVRE, 1991), o fato de a sua 
produção estar determinada pela valorização do valor e pelos ganhos fundiários é uma contradição central. 0 embate entre as classes sociais, demais grupos e indivíduos passa a ocorrer na cidade e a ter a cidade e a vida urbana como o objetivo desses embates.

Da implosão-explosão das cidades pelas indústrias ao processo de metropolização guiado pelo capital rentista

O estudo do fenômeno urbano é múltiplo e complexo, por isso, conta com contribuições de diversos estudiosos com abordagens distintas, mas complementares. Bresciani (1992, p. 18-19), pelo prisma da "multidão", mostra que, na Europa do século XIX, cidades como Londres e Paris já apresentavam um intenso e caótico processo de urbanização como desdobramento de seu processo de industrialização e de racionalização do tempo social. Benevolo (1981) mostrou a urbanização do século XIX na França e na Inglaterra a partir das práticas empregadas pelo recém-nascido urbanismo e suas contradições, que se articulavam às contradições do modo de produção capitalista e aos interesses de classe. Engels (2010), por uma perspectiva de classes sociais, mostrou a situação da classe trabalhadora na Inglaterra do século XIX e revelou como industrialização, proletarização, urbanização e alienação são processos inseparáveis. As contribuições de estudos como esses nos permitem o estabelecimento de um primeiro contato como a natureza do processo de urbanização, mas Lefebvre (2016, p. 78) deu um passo adiante ao mostrar como o espaço foi produzido para as indústrias, que destruíram a "cidade" e suas relações, produzindo em seu lugar a "não-cidade", a "anticidade".

No geral, a "implosão-explosão" das formas e dos conteúdos das cidades, nos termos de Lefebvre (1999), é a consequência da produção do tecido urbano para além das áreas centrais e em direção às periferias. Trata-se da destruição da cidade e de suas relações características; a festa, o encontro, o lúdico, a criação de obras, o gozo. Ademais, os habitantes mais pobres, os trabalhadores, sofrem um novo processo de espoliação comandado pelo Estado e pelos capitais, a periferização. Embora distinto na forma, este processo de espoliação urbano mostra-se tão perverso quanto à "acumulação primitiva", que consiste na expulsão do homem do campo para as cidades, como estudada por Marx (2011, p. 797). Esse processo atinge, em cheio, a classe trabalhadora mais empobrecida. Conforme Harvey (2015, p. 138), em Paris no século XIX, deu-se início à apropriação da cidade pelo "capital imobiliário", por meio da ação do Estado. Embasado por um urbanismo tecnocrático e funcionalista, Haussmann, que ficou à frente das intervenções realizadas em Paris por dezoito anos, dizia que iria trazer a modernidade tão almejada. Entretanto, suas intervenções tinham uma função, claramente, militar, de embelezamento e de adequação da cidade para a atuação dos diversos capitais em busca de capitalização (HARVEY, 2015, p. 138, 139 e 150).

Fatos como esses evidenciam o papel do Estado, que, encarnando a economia política do espaço travestida de urbanismo, tem o espaço com um objeto, tornando-o uma mercadoria (MARTINS, 2000, p. 54). Ademais, a capitalização do e no espaço depende de intervenções estruturantes como a construção do capital fixo urbano, produzidas majoritariamente pelo Estado (TOPALOV, 1979, p. 20). É o que Harvey (2013a, p. 307) chama de capital fixo de tipo "independente" e são as pontes, rodovias, portos, ferrovias, hidrelétricas, etc. que funcionam como valores de uso necessários à reprodução do capital. Devido aos custos elevados, são de responsabilidade do Estado. Além do mais, essa estruturação do espaço a cargo do Estado incide ativamente no preço da terra, atendendo à necessidade de capitalização das rendas fundiárias, como mostram Harvey (2013a), Jaramillo (2010), Almeida e Monte-Mór (2017), Botelho (2007) e outros. A urbanização, nessa interpretação, não é um processo cego e aparentemente sem sujeito que resultaria apenas da 
iniciativa não articulada dos diversos capitalistas individuais concorrentes entre si. Não é a soma simples de uma multidão de processos privados de apropriação do espaço. Há leis imanentes por trás e um planejamento estatal que articula os diversos agentes supracitados, que mobiliza e produz o espaço urbano. Há, também, o outro lado, os demais grupos marginalizados, classes sociais e indivíduos, que, por vezes, exigem ter seus interesses mínimos atendidos, podendo, até mesmo, impor alguns ajustes a essas decisões tomadas.

As zonas urbanas, com toda a sua complexidade, concentram a força de trabalho necessária em grande quantidade, inclusive em excesso, uma localização estratégica para as empresas, o capital fixo necessário à reprodução do capital e as terras urbanas das quais se extrai rendas. 0 "direito à renda" é um direito à parte da renda global obtida por quem tem a posse jurídica das terras e esses ganhos vêm de trabalhos futuros, não da terra em si, pois essa não gera valor (MARTINS; GOMES, p. 125-127). A urbanização tem sido guiada, em larga medida, pela busca por rendas fundiárias, sendo a periferização e a gentrificação desdobramentos (i)lógicos do mercado de solo urbano. Locais que passam por requalificações a cargo do Estado têm, automaticamente, o preço da terra elevado. Desse modo, as diversas remoções de famílias para a construção de rodovias e de diversos equipamentos urbanos, em praticamente todas as metrópoles do planeta, são manifestações de contradições da e na produção capitalista do espaço. São a prova de que o capital, em sua marcha reprodutiva, reproduz as suas contradições pela reprodução dos espaços. Para tal tarefa, o Estado é estrutural e o fará, mesmo que tenha que espoliar (despossuir) a tudo e a todos que se apresentem como barreiras a essa marcha (HARVEY, 2013b, p. 121). As estratégias de superação dessas contradições internas e externas expressam as violências empregadas para que o capital consiga se reproduzir por meio do solo urbanizado. Produzir espaços se enquadra no "processo de reprodução do capital", que Bihr (2003, p. 8) buscou em Marx, um processo em que o capital precisa incorporar todo o conjunto da práxis social para se reproduzir, incluindo o espaço.

Lefebvre foi um dos primeiros a se dar conta disso e, acertadamente, mostrou que o espaço social entrou para o rol das raridades, tornou-se uma mercadoria, e isso o faz, além de valor de uso, valor de troca (LEFEBVRE, 2016, p. 52). A função do Estado com sua economia política do espaço travestida de urbanismo é colocar no campo cego essas contradições do espaço, substituindo à práxis social por suas representações do espaço e da vida social (LEFEBVRE, 1999, p. 141).

Tal contexto faz com que os rentistas se aproveitem e realizem investimentos para a extração da renda fundiária, intensificando a apropriação do solo urbano como mercadoria. Conforme Botelho (2007, p. 8-11), essa apropriação só se processa por meio de parcerias entre o Estado e os capitais rentista e bancário, sendo que este último reduz o tempo de circulação dos capitais investidos pelas construtoras, transformando os produtos imobiliários em ativos financeiros que rendem juros, em mercadorias. Os bancos intermedeiam a transformação de recebíveis imobiliários em títulos vendidos nas bolsas de valores comercializados pelos incorporadores do solo urbano. Em troca desse "adiantamento" às construtoras, os compradores dos títulos recebem elevados juros pelo tempo de retorno desses valores adiantados. Para Vedrossi e Monetti (2002, p. 4-5), o funcionamento desse sistema ocorre da seguinte maneita:

a securitização de recebíveis imobiliários consiste na emissão de instrumentos de securitização que espelhem o portfólio de créditos provenientes de transações imobiliárias, como por exemplo, a aquisição de imóveis residenciais. 0 originador destes créditos, que possui em sua carteira os recebíveis imobiliários, tem uma posição de financiador da aquisição imobiliária. [...] o capital de giro da empresa originadora está vinculado ao financiamento desta carteira. (VEDROSSI; MONETTI, 2002, p. 4-5). 
Essa estrutura parece solucionar a crise de acumulação dos capitais, mas apenas a amplia quando se pensa no conjunto do modo de produção. Os capitais rentistas obtém "fatias cada vez maiores de excedente às expensar de capitalistas industriais, o que significa retornos decrescentres para os produtores diretos" (HARVEY, 2019, p. 26). No limite, a alocação de grandes fatias de capitais em uma reprodução fictícia não passa de uma ficção, pois exploram pouco trabalho vivo e não produzem valor. O capital fictício apenas amplia a crise estrutural do capitalismo, pois não gera valor, somente, capitaliza os valores produzidos no processo protutivo real. Os consumidores são facilmente aprisionados por essas engrenagens, pois dependem dessa estrutura para adquirir mercadorias tão caras como as habitações. Essas tramas entre os capitais rentista e financeiro permitem que a renda fundiária urbana seja capitalizada e a crise da acumulação de capital postergada. Na realidade, ampliada.

Tendo em conta os aportes teóricos mais amplos esboçados nesse pequeno resgate da literatura, busca-se no fenômeno da metropolização de Belo Horizonte elementos para melhor compreender os processos que envolvem a reprodução capitalista do espaço. Em resumo, a análise da urbanização carece de investigações que alcancem as estratégias do capital rentista, não apenas a ação do capital industrial.

\section{As parcerias entre Estado e capital na produção do espaço belo-horizontino}

[...] a evolução urbana deve ser estudada sob seus diferentes aspectos, mas sempre do ponto de vista geográfico. Por isso, em primeiro lugar convém analisar a evolução do espaço [...] (MONBEIG, 1957, p. 45).

Belo Horizonte, fundada em 12 de dezembro de 1897, possui especificidades em seu contínuo processo de produção do espaço se comparada a outras cidades brasileiras. O município foi fundado em um momento histórico que é crucial para compreensão da formação social brasileira contemporânea. Sua idealização e concepção, praticamente, coincidem com o período da proclamação da república brasileira, em 15 de novembro de 1889. Seus construtores, com forte inspiração no urbanismo modernista e funcionalista francês, marcado pela reestruturação de Paris a cargo de Haussmann, desenharam a planta de Belo Horizonte apoiados nos preceitos positivistas do fim do século XIX (SALGUEIRO, 1997, p. 154).

Nesse período, o capitalismo desbravava o mundo e suas relações de produção começavam a alcançar os lugares mais remotos do planeta. Hobsbawm (1979, p. 67-69) denomina esse momento, o século XIX, de "a era do capital", cuja "expansão sem precedentes" começou a criar as bases físicas e estruturais para que o capitalismo se tornasse globalizado como é hoje em dia. O autor mostra o que levou a um mundo feito a imagem e semelhança do capital, ao descrever como o conhecimento do mundo foi ampliado, como o comércio se expandiu de um modo jamais visto e como a infraestrutura básica para a circulação de mercadorias começou a ser construída e ou ampliada. 0 autor aponta que os engenheiros e arquitetos estavam na linha de frente dessa expansão (HOBSBAWM, 1979, p. 67-69). Nesse processo, a ideia de desenvolvimento, de vanguarda e de moderno começou a ser, aos poucos, atrelada à industrialização e ao modo de vida urbano.

Foi nesse contexto, fim do século XIX e início do XX, que parte significativa das elites brasileiras, começou a planejar uma futura modernização do Brasil, no sentido de uma sociedade urbano industrial. Para esse fim, tiveram que submeter o capital agrário exportador à indústria e dar continuidade ao processo de proletarização da força de trabalho. Esse processo foi relativamente 
longo e, somente na década de 1930, começou a tomar forma, devido a articulações entre forças políticas, econômicas e sociais brasileiras, como bem analisou Mendonça (2012). Nascida sob o signo dessa modernidade e anunciada como uma cidade alinhada com os preceitos sanitários da época, Belo Horizonte foi construída para ser a nova capital do estado de Minas Gerais e para comportar o staff administrativo do governo. Sobre o antigo Curral Del Rey brotou uma nova municipalidade, que foi se reproduzindo ao longo do século XX. Tal expansão deu as costas às práticas de seus moradores originais, excluídos dos limites da Avenida do Contorno. Belo Horizonte foi pensada para ser metrópole, para ser "o catalisador da modernização urbano-industrial mineira; para romper com as relações conservadoras do arcaico e instituir os fundamentos do moderno e do progresso, que, indubitavelmente, passou pelo projeto industrial mineiro" (GOMES, 2012, p. 198).

Construída para abrigar os funcionários e a estrutura da administração do estado de Minas Gerais e com um direcionamento ao encontro com a modernização do Brasil, já em curso,

Belo Horizonte nasceu sob o signo da industrialização, mas esta the foi negada nas dificuldades de seus primeiros governos. As crises econômicas da virada do século, as lutas políticas dos mineiros das minas e dos gerais, as alianças entre interesses antagônicos face ao controle sobre a capital e as dificuldades em resolver questões regionais e urbanas, como transportes e energia, retardaram a maturação industrial de Belo Horizonte (DINIZ, 1981 apud MONTE-MÓR, 1994, p.15).

Belo Horizonte, em suas primeiras décadas, não conseguiu emplacar sua industrialização pelo fato de seu território não ter as "condições gerais de produção" necessárias. Nesse período, o mundo ainda estava conhecendo o fordismo e vivia sob a batuta do liberalismo econômico clássico, modelo que viria a ruir com a crise de 1929. A partir da década de 1940, o Estado teve papel decisivo. O espaço belo-horizontino foi marcado por intervenções estruturantes significativas a cargo do Estado, que mostram essa articulação com os interesses do capital industrial. Houve diversas novas obras estruturantes do território promovidas pelo Estado referentes à infraestrutura urbana como ruas e avenidas ligando a área central aos novos loteamentos e bairros. Tais intervenções visavam tornar Belo Horizonte mais atraente para o nascente capital industrial mineiro, fazendo, enfim, decolar a sua industrialização. Jaramillo (2013, p. 2-3) mostra que, na America Latina, entre as décadas de 1940 e 1960, predominou um tipo de "urbanismo corbuseriano, funcionalista" marcado pela forte presença do Estado para orientar as ações dos particulares e mitigar as contradições da urbanização. Em outras palavras, atrelado ao paradigma da modernidade e aos critérios operadores da "Carta de Atenas", "o Estado deveria planificar o desenvolvimento da cidade" (JARAMILLO, 2013, p. 2-3).

Desse modo, mediante o planejamento estatal centralizador, a metrópole belo-horizontina passou a crescer, invariavelmente, para o oeste e para o norte (COSTA, 1994, p. 56). De acordo com Mendonça e Costa (2003, p. 75), ao longo do século XX, o binômio investimento público/capital imobiliário produziu a metrópole belo-horizontina crescentemente segregada: nos domínios da Avenida do Contorno se estabeleceram as elites e, ao longo dos seus eixos de expansão oeste e norte, consolidou-se a dinâmica da produção extensiva de loteamentos para os trabalhadores e segmentos de menor renda. O primeiro eixo de expansão implantado em Belo Horizonte para esse fim foi o oeste, com o início das obras do parque industrial de Contagem, em 1941 (SOUZA; BRITO, 2008, p. 3). No processo de desconcentração das indústrias do centro de Belo Horizonte para Contagem foi aproveitada a existência da BR-381, pois já passava pela área. Esse distrito industrial, a Cidade Industrial Juventino Dias, foi construído em 1946, em um distrito da cidade de Betim, hoje, o município de Contagem. A construção da cidade industrial de Contagem culminou na criação da Companhia 
Energética de Minas Gerais (CEMIG), em 1952, para suprir a falta de energia elétrica que limitava a industrialização da metrópole.

Esse eixo de expansão, intencionalmente, direcionou o crescimento do tecido urbano de Belo Horizonte e as oportunidades de capitalização das rendas fundiárias para a região oeste da cidade. Com a consolidação das indústrias, nas décadas seguintes, o crescimento do tecido urbano de Belo Horizonte foi muito significativo ao longo da via que liga os dois municípios. Essa foi a primeira frente de conurbação da Região Metropolitana de Belo Horizonte e é o resultado direto desse momento.

Esse processo de expansão periférica das indústrias da cidade foi acompanhado de perto pelo capital rentista, que se aproveitou das intervenções estatais para auferir rendas oriundas da valorização dos imóveis próximos a tal eixo de expansão. No centro de Belo Horizonte, os antigos galpões deixados para trás pelas indústrias entraram em um processo de degradação por décadas. Somente na década de 1990 os antigos e degradados galpões industriais localizados na Avenida dos Andradas começaram a ser "(re)valorizados" pelo poder público, por uma estratégia de requalificação do centro da cidade, dando-Ihes uma faceta cultural voltada para o consumo da própria cidade.

Por seu turno, a criação do complexo arquitetônico da Pampulha, um complexo de alto luxo de lazer, turismo e moradia destinado aos estratos com maior poder aquisitivo, inaugurado em 1943, direcionou do crescimento do tecido urbano de Belo Horizonte para a porção norte do município. Ademais, a abertura da Avenida Antônio Carlos, em 1943, estimulou a ocupação da porção norte do município por estratos com menor poder aquisitivo (ANDRADE, 2003, p. 181). Em documento publicado pelo próprio poder público da cidade, lê-se;

(...) Fizemos, então, desapropriar, amigavelmente, uma faixa de terra de 125 metros de largura, numa extensão de 6.500 metros, até a barragem da represa. Dos 125 metros de largura, apenas 25 , ou seja, a mesma largura da parte anteriormente concluída, se destinaram à avenida, pois a municipalidade reservou ao longo de toda a nova via pública, duas faixas de 50 metros de cada lado, para futuramente alienar o que, com a natural e rápida valorização, será uma fonte de renda para o Município (BELO HORIZONTE, 1942, p.22).

A passagem acima aponta para o fato de que, no planejamento referente à construção da Avenida Antônio Carlos, já eram esperados os ganhos com as rendas fundiárias diferenciais. Certamente, o preço que foi pago nas desapropriações não se aproxima do praticado após as intervenções. O documento, porém, não menciona o fato de que, certamente, o capital rentista privado, também, se apropriaria dessa renda diferencial.

Quanto ao processo de metropolização de Belo Horizonte no sentido norte, Souza e Brito (2008, p. 3) afirmam que o avanço em direção aos municípios ao norte também se deu pela abertura das Avenidas Cristiano Machado e Antônio Carlos, juntamente, com a construção de distritos industriais em Santa Luzia e Vespasiano na década de 1960. Assim, embora a dinâmica contraditória do avanço da periferia de Belo Horizonte para os municípios vizinhos já fosse uma realidade, tal dinâmica adquiriu certa "formalização" e foi ampliada com a institucionalização da região metropolitana pela Lei Complementar $n^{0}$ 14, de 8 de junho de $1973^{3}$. No Brasil, a formação de um espaço metropolitano já acontecia na prática pela incorporação do solo urbano dos municípios vizinhos à cotidianidade e aos tecidos urbanos dos grandes municípios, mas sua "formalização" ocorreu apenas no âmbito do governo militar.

\footnotetext{
3 A Região Metropolitana de Belo Horizonte contava com 14 municípios quando foi formalizada; Belo Horizonte, Betim, Caeté, Contagem, Ibirité, Lagoa Santa, Nova Lima, Pedro Leopoldo, Raposos, Ribeirão das Neves, Rio Acima, Sabará, Santa Luzia e Vespasiano. Atualmente, são 34 municípios.
} 
No contexto regional e metropolitano, a conexão entre os diferentes lugares e suas atividades ocorre nos moldes de uma "rede urbana". A rede urbana, nos termos de Corrêa (1989, p. 47-49), é uma "dimensão da realidade social", que reflete a "divisão territorial do trabalho", articulada e definida pela hierarquia urbana e por uma especialização funcional. Corrêa nos apresenta uma análise geográfica de um processo econômico que alcança patamares regionais. Em sua perspectiva, as grandes metrópoles são os centros de cumulação do capital dentro das redes urbanas, crescendo de acordo com a presença das grandes corporações (CORRÊA, 1989, p. 50). Na rede urbana ocorre a criação, apropriação e circulação dos excedentes, processo que depende de pontos no território, os centros urbanos, e cada um cumpre determinada função (CORRÊA, 1989, p. 52). As migrações de mão-deobra rural para as cidades, por seu turno, são frutos do fator concentrador das metrópoles, que atraem a maior parte dos excedentes, das rendas fundiárias, dos investimentos do Estado, das indústrias e do comércio (CORRÊA, 1989, p. 64).

A criação das regiões metropolitanas foi orquestrada pelo planejamento a cargo do Estado ditatorial brasileiro e sua política de integração econômica do território nacional. A formalização das regiões metropolitanas, na década de 1970, tinha o objetivo de organizar o sistema produtivo do país pela hierarquização dos seus espaços urbanizados, que estavam pouco conectados e mergulhados em déficits estruturais para a reprodução do capital. Na prática, as regiões metropolitanas funcionam como atrativos para investimentos, por conta do seu grande potencial de consumo, de fornecimento de mão-de-obra barata e de um renovado estoque de terras baratas para a incorporação imobiliária. A saturação e a estruturação do espaço das grandes cidades levam ao alto preço da terra para incorporação imobiliária, tornando os municípios das regiões metropolitanas mais atraentes para a instalação dessas atividades.

Os municípios ao norte de Belo Horizonte foram incorporados, de uma vez por todas, a espacialidade e a cotidianidade da metrópole com a construção dos conjuntos habitacionais para as populações de baixa renda "expulsas" da capital, em Santa Luzia e Vespasiano, no final da década de 1970, com recursos do SFH/BNH ${ }^{4}$. Na Região Metropolitana de Belo Horizonte e em grande parte das grandes cidades brasileiras, a fragmentação social dos espaços urbanos representada pelas favelas, periferias sem estrutura urbana, pelos conjuntos habitacionais para os trabalhadores mais pobres e, também, pelos condomínios fechados para a população de alta renda são manifestações do acesso diferencial das classes ao espaço amplificada e ratificada nas alinanças entre Estado e os diversos capitais, que trabalha juntos para submeter as cidades às leis do mercado.

O que ocorreu no período áureo do SFH/BNH, décadas de 1960, 1970 e 1980 é elucidativo. De acordo com Botelho (2007, p. 8), por meio de recursos arrecadados com o FGTS ${ }^{5}$ dos trabalhadores, o governo militar brasileiro, com o auxílio de bancos públicos, financiava habitações para as camadas de renda média e baixa. Porém, uma contradição marcante foi a expulsão para as periferias mais distantes, dentro ou fora das metrópoles, da população trabalhadora de mais baixa renda, mediante uma lógica de mercado calcada nos ganhos com a renda da terra. Em grandes metrópoles como Belo Horizonte, São Paulo e Rio de Janeiro, onde os investimentos estatais em infraestrutura urbana eram mais concentrados o preço da terra era mais elevado, a moradia dos mais pobres tornou-se praticamente impossível.

Autores como Jaramillo (2013) e Kowarick (2000) trazem à luz o fato de as autoconstruções terem representado a forma predominante de acesso à moradia pela classe trabalhadora mais pobre nas perierias das cidades latinoamericanas. Para Kowarick (2000, p. 92), entre as décadas de 1950 e 
1970, a autoconstrução foi a modalidade predominante na urbanização de cidades como São Paulo. Concomitantemente, houve uma exclusão socioespacial derivada de investimentos públicos desiguais nas políticas de habitação, o que acirrou, ainda mais, a fragmentação dos espaços urbanos e tornou a distribuição das classes sociais no tecido urbano facilmente identificável pelo olhar. Assim, a "gentrificação" (SMITH, 2007) do e no espaço das metrópoles não foi solucionado como prometido pelo governo militar, mas, ao contrário, foi ampliada.

O crescimento populacional das cidades era uma realidade em todo o país, cuja urbanização tornou-se uma realidade na década de 1970. Por conta dos processos supracitados, a urbanização excludente em Belo Horizonte fez a periferia de seu tecido urbano romper vorazmente suas fronteiras municipais, especialmente para a sua porção norte. Esse processo, que foi recorrente nas principais cidades brasileiras nesse período, representou a consolidação da condição de centralidade das metrópoles dentro dos arranjos espaciais metropolitanos e de determinada estrutura voltada para uma competição acirrada dentro da divisão do trabalho em escala local, regional, nacional e global. Vale a lembrança de que o capitalismo, a partir da década de 1970, aderiu à chamada reestruturação produtiva (HARVEY, 2012), descentralizando as indústrias pelo mundo e demandando estrutura para a produção em países de industrialização tardia como o Brasil. Verifica-se nessas estratégias de produção do espaço em que o Estado e o capital se articulam, que a questão dos limites municipais não representa uma barreira à reprodução ampliada do capital. Se necessário, organiza-se os territórios e regiões de modo a submeter as suas formas e seus conteúdos sociais à logica da reprodução ampliada do capital.

Na década de 1990, foi consolidando-se a produção do eixo de expansão sul, um espaço que possui a particularidade de a quase totalidade de sua nova população migrante ser composta por pessoas com alta remuneração, que fugiam dos "problemas urbanos" de Belo Horizonte em direção ao município de Nova Lima (ANDRADE, 2003, p. 184). Esse eixo de expansão foi consolidado pela construção do BH Shopping, na divisa entre Belo Horizonte e Nova Lima, e pela construção de condomínios de alto luxo para famílias de alta renda como o Alphaville. Segundo Costa (2006, p. 112113), no eixo de expansão sul,

(...) o Estado passou por um processo de modernização ecológica da regulação da expansão urbana, por meio da incorporação crescente de instrumentos e mecanismos da regulação ambiental nas atividades urbanas (...), pelo lado do capital imobiliário observa-se a transformação e progressiva complexificação do setor, associado à modificação do produto oferecido, no qual a natureza, progressivamente capitalizada, desempenha o papel de transformar valores de uso em renda fundiária, seja em resposta à legislação, seja criando demandas de mercado associadas a novos conceitos de habitação (COSTA, 2006, p. 112-113).

Oliveira (1977, p. 75) mostra que o Estado desempenha um duplo e contraditório papel na sociedade capitalista, pois é o gestor do território e dos interesses da população, além de ser o viabilizador dos negócios da burguesia. A propósito,

não pode o Estado solucionar o chamado problema de transporte urbano? Pelo tamanho do excedente que maneja, pode, mas, se esse excedente provém em parte da produção automobilística, então não pode. Pode o Estado solucionar o problema da poluição? Tendo tanto chão nesse país, parece que se poderia descentralizar a indústria, principal poluidora, mas o chão da pátria não é chão, é capital. (OLIVEIRA, 1977, p. 75).

Nesse tópico foi traçado uma espécie de "making off" do processo de metropolização de Belo Horizonte. Conforme começamos a perceber pelo caso de Belo Horizonte, a atuação do Estado não é nada dúbia. Por suas ações, mostra-se guiado pelo mercado, portanto, articulado aos interesses 
dos capitais. No caso brasileiro, o Estado, norteado pela valorização do valor, forneceu infraestrutura principalmente para parte das cidades e o restante permaneceu desprovido de condições de garantir a cidadania aos seus moradores. Em geral, esse descaso atinge com mais intensidade a parte mais empobrecida da classe trabalhadora, que não pode pagar pela parte da cidade mais bem equipada pelo poder público. Neste contexto de formalização dessa rede urbana, dessa cotidianidade metropolitana, a vida nos municípios periféricos e suas terras foram incorporadas à cotidianidade metropolitana.

\section{O período pós Constituição Federal de 1988 e a "nova" divisão intermunicipal do trabalho}

Após o período da ditadura militar, encerrada em 1984, e com a promulagação da Constituição Federal de 1988, houve o fortalecimento dos municípios enquanto gestores de suas políticas públicas (ROLNIK; SOMEKH, 2003, p. 95). Foi devolvida a "autonomia" de organização do espaço municipal à esfera local que, desde meados dos anos 1960, esteve nas mãos do governo militar centralizador. A retração do papel do governo federal no financiamento urbano desacompanhada de condições que dessem autonomia financeira aos municípios, no contexto de crise global, abriu caminho no Brasil para uma verdadeira "guerra fiscal" entre os estados e municípios. Vale ressaltar que a reprodução dos grandes capitais estava descentralizada pelo planeta, desde a década de 1970, operando em rede buscando por vantagens locacionais e produtivas (CASTELLS, 1999; SANTOS, 2012). Harvey (2005a), estudando o contexto europeu, afirma que houve a passagem para uma espécie de "empresariamento urbano" marcado pelo desenvolvimento desigual dos municípios. Essa tendência se aplica a partes significativas de grandes e médios muicípios brasileiros.

No contexto de protagonismo da escala local, cada prefeito delineia suas estratégias para atrair investimentos e empresas, pois há a possibilidade de negócios diretos entre as empresas e os governos municipais. Esse fato expressa uma demanda dos grandes capitais por mobilidade em escala global, pela "queda de barreiras espaciais" (HARVEY, 1992; 2019), em busca de saídas para a crise estrutural. Dessa maneira, a inserção ampliada das municipalidades e da reprodução social local na economia globalizada se intensificou. De acordo com Harvey,

\footnotetext{
(...) a queda de barreiras espaciais não implica o decréscimo da significação do espaço. [...] 0 aumento da competição em condições de crise coagiu os capitalistas a darem muito mais atenção às vantagens locacionais relativas, precisamente porque a diminuição de barreiras espaciais dá aos capitalistas o poder de explorar, com bom proveito, minúsculas diferenciações espaciais (HARVEY, 1992, p. 265).
}

Assim, o planejamento estratégico dos municípios passou a ser algo indispensável nesse processo concorrencial com outras municipalidades. Criou-se uma corrida desesperada por investimentos, na qual os municípios chegam a abrir mão de impostos e a flexibilizar suas legislações ambientais e urbanas para ser mais atrativos. A intensificação das parcerias público-privadas é o resultado da possibilidade dos governos municipais dialogarem diretamente com os capitais. Nos municípios do Eixo Norte da $\mathrm{RMBH}^{6}$, o planejamento estratégico de Lagoa Santa, por exemplo, caracteriza bem esse cenário. As políticas do município têm sido voltadas para a atração de diversas empresas, indústrias e empreendimentos "imobiliários"7 para que a cidade consiga ser competitiva

60 Eixo Norte (ou Vetor Norte) da Região Metropolitana de Belo Horizonte é composto por oito municípios: Ribeirão das Neves, Pedro Leopoldo, Confins, São José da Lapa, Vespasiano, Lagoa Santa, Santa Luzia e Jaboticatubas.

7 "Capital Imobiliário" é um termo contraditório, pois "capital" implica movimento do valor e não pode haver paralisações (MARTINS; GOMES, 2009, p. 126). 
dentro dessa nova divisão regional trabalho. Há, portanto, um planejamento estratégico com uma abordagem regional a cargo dos governos estaduais, entretanto, os municípios organizam seus territórios e negócios individualmente para atrair os capitais individuais. De acordo com o secretário de planejamento do município de Lagoa Santa', no ano de 2011,

\begin{abstract}
todo o planejamento de Lagoa Santa gira em função do território, organizar o território. (...) Um ponto fundamental desse processo de novos parcelamentos é incentivar o empreendedor a parcelar, mas, também, a estar ciente das leis locais. (...) Para o município estão previstos a implantação da Faculdade de Ciências Médicas e do Centro Aeroespacial, onde 80\% dos militares da aeronáutica brasileira serão formados. (...) Lagoa Santa investe em hotelaria e centros de convenções para atrair o turismo de negócios, mas poderão se instalar no município empresas de grande porte como a Gol e a Foxconn. Essa última, se vier, vai mudar a dinâmica da região mais que a FIAT, em Betim. (...) Se o Estado fizer a parte dele, Lagoa Santa terá, em 2030, cerca de 300.000 hab9
\end{abstract}

$\mathrm{Na} \mathrm{RMBH}$, o Estado teve, e ainda tem, uma função central no fornecimento das chamadas condições gerais de produção e circulação dos capitais, mas ao fornecimento de condições verdadeiramente humanas de vida às pessoas não emprega o mesmo empenho. Pensando no caso da habitação, pode-se dizer que o acesso a esse bem fundamental ficou, e ainda está, intermediado pelas leis de mercado e nas mãos do capital rentista. Desse modo, a metrópole capitalista, voltada para a acumulação e para o rentismo, se mostra anticidadã (MARTINS, 2001). Apesar de o Estado promover ações com o discurso da inclusão social dos mais pobres e de ter obtido alguns resultados significativos por meio de programas como o Minha Casa, Minha Vida ${ }^{10}$, verifica-se que não há mudanças significativas na lógica de incorporação do solo urbano ao capital. Houve, na realidade, uma nova rodada de capitalização das rendas fundiárias urbanas com investimentos públicos federais para "aquecer" o setor da construção civil e os ganhos com os juros dos financiamentos dos imóveis. É digno de nota que, em um país como o Brasil, cujos recursos e investimentos estatais chegam somente para os mais ricos, o fornecimento de urbanidade a uma camada mais empobrecida da classe trabalhadora já é uma verdadeira revolução. Com algumas medidas anunciadas pelo governo de Michel Temer, em 2017, como a redução dos valores financiados pelo Estado, o referido programa social teria ainda mais dificuldade de atender aos mais pobres, atenderia apenas aos estratos de renda media. Com isso, no que tange o acesso dos mais pobres, houve uma regressão de décadas na política habitacional do Brasil ${ }^{11}$.

De forma geral, observa-se que no processo de produção do espaço da e na RMBH, a expulsão das camadas de baixa renda do "valorizado" solo da capital e o crescimento das áreas periféricas foram simultâneos e são a materialização dos processos de "despossessão" (HARVEY, 2013b) dos trabalhadores urbanos. Esse processo pode ser caracterizado como o resultado das articulações entre Estado, capital rentista e os bancos, visando à apropriação do solo urbano para a capitalização das rendas fundiárias. Mais especificamente, o morar na cidade segue dependendo do mercado, pois o espaço social tornou-se fraturado, fragmentado em guetos, e a degradação da vida urbana segue sua marcha ascendente.

No atual processo de metropolização brasileiro, em que há um grande municipalismo em relação ao planejamento e à gestão territorial, verifica-se que alguns instrumentos de política urbana

\footnotetext{
8 Outras análises acerca do caso de Lagoa Santa estão em: SIFFERT, P. V.; SANTOS, T. A.; SENA, C. C. (2012). Urbanização, natureza e produção do espaço na era da cidade empresa: caso do município de Lagoa Santa-MG.

9 Entrevista realizada com o secretário de planejamento do município de Lagoa Santa, no ano de 2011.

10 Programa social criado em 2009 pelo governo do presidente Luiz Inácio da Silva.

11 Acerca desse tema, Raquel Rolnik faz uma rápida, mas precisa análise em seu blog. Disponível em: https://raquelrolnik.wordpress.com/tag/minha-casa-minha-vida/ Acesso em: 23 fev. 2017.
} 
previstos no "Estatuto da Cidade", de 2001, como as "Operações Urbanas Consorciadas - OUC", garantem novas rodadas de capitalização das rendas da terras sob um discurso da legalidade. Para Martins e Gomes (2009, p. 133), as OUC, previstas no artigo 34 do Estatudo da Cidade, são os instrumentos que "definem a possibilidade de emissão pelo poder público de certificados potenciais adicionais de construção que, por sua vez, podem ser negociados livremente e assim adquiridos por investidores privados".

Mesmo os municípios das periferias metropolitanas de Belo Horizonte, estão restringindo a moradia dos mais pobres em seus territórios, utilizando estratégias que passam diretamente pelas possibilidades contidas na própria legislação urbana. Medidas para o controle do uso e do parcelamento do solo urbano definidos nos "Planos Diretores" municipais incentivam a maior capitalização da renda da terra e o controle dos elementos que a desvalorizam. Por exemplo, ao restringir a construção de loteamentos com lotes menores que $500 \mathrm{~m}^{2}$ em determinada área em seus planos diretores, os municípios também restringem a possibilidade de compra desses imóveis pela população de baixa renda. Isso pode ser explicado pelo fato de o tamanho dos lotes incidir diretamente no preço desses imóveis. Sabendo que as pessoas de alta renda querem se distanciar dos mais pobres e que a população de baixa renda somente consegue comprar lotes menores, o poder público municipal interfere no parcelamento do solo por meio de sua "Lei de Zoneamento" para designar as áreas destinadas a cada faixa de renda desejada. Aos mais pobres, poucos locais são designados. Ademais, Martins e Gomes (2009) destacam

\begin{abstract}
a reafirmação e ampliação, contemplados no Estatuto da Cidade, dos fundamentos da mobilização da propriedade territorial no âmbito da valorização do espaço. 0 desafio teórico consiste, portanto, em demonstrar que as determinações concretas da urbanização capitalista não apenas permanecem intocadas pelo aprisionamento da política nas formas do Estado, como são reiteradas e desenvolvidas as intrincadas contradições que envolvem a reprodução social das metrópoles, e nelas se sintetizam, especialmente se considerarmos a decisiva importância que a capitalização da renda da terra desempenha em tal processo (MARTINS; GOMES, 2009, p. 124)
\end{abstract}

À medida que os municípios passaram a ver os mais pobres como elementos economicamente indesejáveis em seus territórios, estas estratégias previstas em lei criaram um sério problema para o acesso destes ao solo urbano, pois tornam-se barreiras "invisíveis". É nítida essa exclusão e as repugnantes explicações por parte dos poderes públicos municipais tocam no fato de os mais pobres demandarem mais dos serviços públicos como saúde e educação e, ainda, trazerem certos estigmas sociais para os municípios, o que afastaria as elites e a classe média. Na realidade, a preocupação central dos governos municipais reflete os preconceitos de uma elite atrasada, para a qual a presença dos mais pobres algo negativo. O mercado imobiliário voltado para as elites entende, então, que os pobres interferem negativamente na capitalização das rendas da terra. O que uma justificativa como essa mostra de coerencia do ponto de vista economico, mostra de desumanidade e falta de cidadania.

$\mathrm{Na}$ RMBH e em outras metrópoles brasileiras, verifica-se que aos trabalhadores de mais baixa renda resta morar nos locais antes de os serviços e da infraestrutura básica serem implantados, pois somente assim conseguem ter acesso ao solo urbano, seja pela invasão ou pela compra mais barata. Os mais ricos e as empresas, por seu turno, instalam-se nos lugares somente após o amplo fornecimento da infrastrutura e dos serviços básicos. No entanto, à medida que a infraestrutura vai sendo implantada pelo Estado, a própria dinâmica da capitalização do solo urbano ajuda a promover uma nova rodada de expulsão de pessoas de baixa renda que moraram nesses locais por décadas, bem antes de qualquer infraestrutura básica ser instalada. Nesse sentido, a contrapartida a esse 
processo por parte dos trabalhadores de mais baixa renda é uma nova invasão de propriedades privadas subutilizadas por seus proprietários a espera de alterações no preço do solo, a compra ou o aluguél de moradias nas periferias ainda mais distantes dos seus postos de trabalho e de qualquer urbanidade.

\title{
A metropolização de Belo Horizonte a partir da criação do Vetor Norte de desenvolvimento
}

\begin{abstract}
Essa é uma característica importante da modernidade: o futuro deverá, a qualquer preço, constituir-se um futuro de progresso. Mesmo que o presente se comprometa indefinidamente, onerase todo o presente por um futuro que jamais se aproxima ou, quando muito, achega-se com a maximização da exclusão (HISSA, 1997, p. 2).
\end{abstract}

Procurando resolver os gargalos da acumulação na RMBH, o Governo do Estado de Minas Gerais iniciou, na metade da década de 2000, diversas intervenções estruturantes no Eixo Norte da RMBH, visando torná-lo "atrativo" quanto à localização industrial e à capitalização das rendas fundiárias. Os outros dois eixos de expansão utilizados nas décadas anteriores, o oeste e o sul, já davam sinais de esgotamento e/ou apresentavam conflitos de uso da terra mais difíceis de ser solucionados. No caso do Eixo Sul da RMBH, por exemplo, empresas mineradoras são proprietárias de grande parte das terras de municípios como Nova Lima, o que torna cara a incorporação de novas terras para a apropriação intensiva do capital rentista e do setor produtivo. Nesse caso, o alto custo da terra influenciaria diretamente na queda dos ganhos capitais que lá seriam investidos e seria muito oneroso para o Estado, que teria que arcar com os altos custos dos investimentos em infraestrutura urbana.

Em vista disso, o Eixo Norte passou a ser o principal eixo de expansão da Região Metropolitana de Belo Horizonte, tanto que, em 2008, uma empresa de Cingapura chamada Jurong Consultants foi contratada pelo Governo do Estado de Minas Gerais para criar um plano estratégico para o desenvolvimento econômico da região. O plano do governo de Minas Gerais consistia em tornar o Eixo Norte da RMBH uma importante centralidade dentro da reprodução dos capitais atuantes, não apenas nas escalas local e regional, mas global. De acordo Raphael Chua, gerente da Jurong Consultants,

os prefeitos precisam se organizar para preparar o território para os novos investimentos. A infraestrutura precisa crescer junto com o crescimento econômico. Belo Horizonte amanhã não vai competir só com São Paulo ou Rio de Janeiro, mas com Tóquio e Paris também. É preciso que a cidade tenha um plano estrutural que permita aos investidores chegar aqui ${ }^{2}$.

Nessa fala, fica evidente a articulação entre escalas distintas de planejamento estatal para o fornecimento das condições gerais de produção. Com a reestruturação territorial do Eixo Norte $\mathrm{RMBH}$, levada a cabo pelo governo estadual, os poderes públicos municipais passaram a equipar seus territórios para que os diversos capitais locais pudessem absorver os "desdobramentos" econômicos dessa reestruturação. No planejamento desenvolvido pelo estado de Minas Gerais com assessoria da Jurong Consultants, a reestruturação do Aeroporto Internacional Tancredo Neves foi peça estrutural. A partir dessas intervenções territoriais, havia a ideia de tornar o Eixo Norte um "Vetor de desenvolvimento" na RMBH. O chamado Vetor Norte "denomina uma das frentes de expansão 
urbana do território metropolitano que mantém fortes relações físico-territoriais, sociofuncionais e econômicas com a metrópole" (PBH, 2010, p. 12). São quatorze os municípios que a compõe; Lagoa Santa, Confins, Santa Luzia, São José da Lapa, Pedro Leopoldo, Belo Horizonte, Capim Branco, Matozinhos, Vespasiano, Ribeirão das Neves, Jaboticatubas, Taquaraçú de Minas, Baldim e Nova União. O MAPA 1 mostra a localização das principais intervenções no contexto do Vetor Norte.

Mapa 1 - As principais intervenções do Estado no Vetor Norte

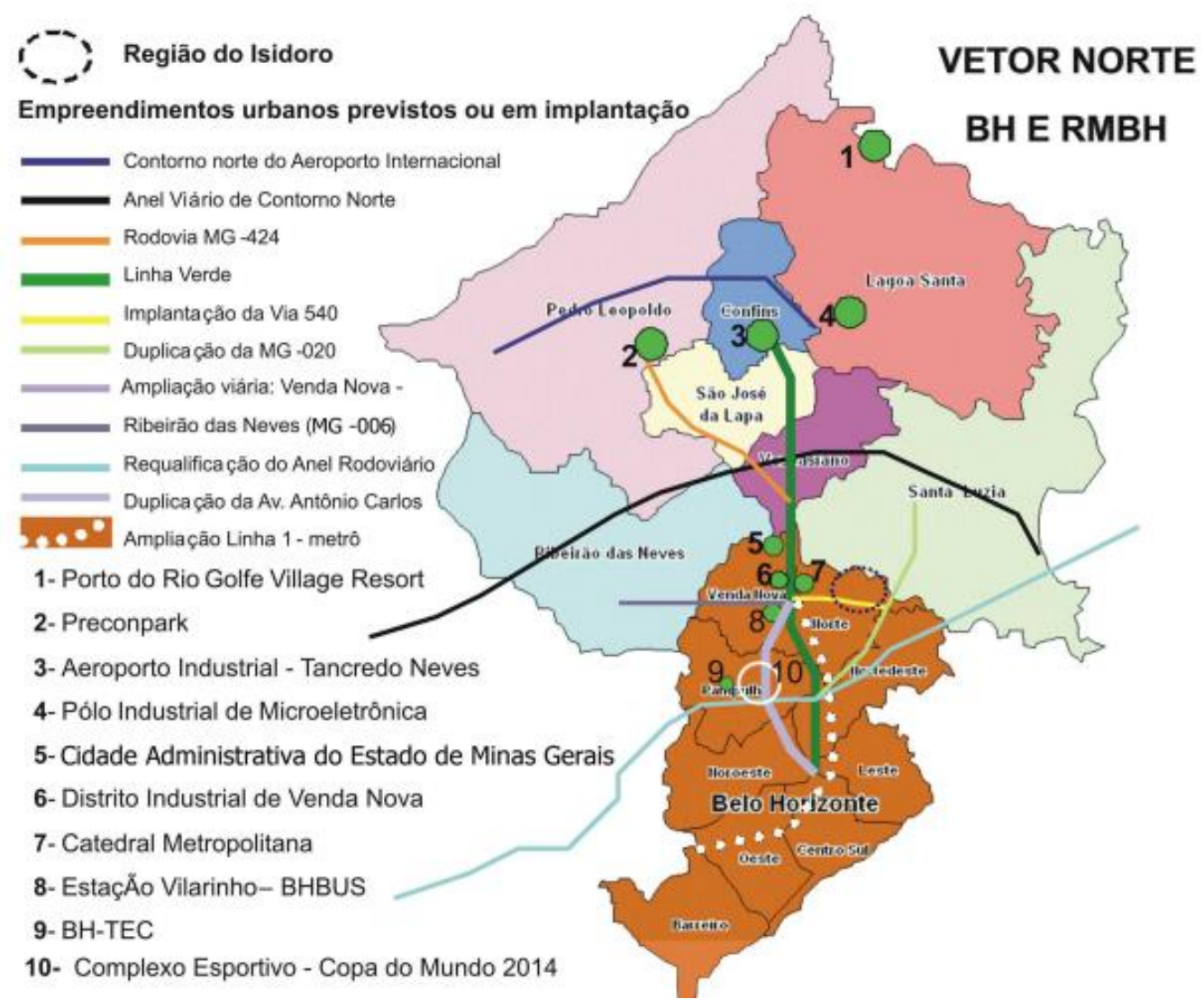

Fonte: Prefeitura de Belo Horizonte, 2010, p. 12.

A definição desses treze municípios que passaram a compor o Vetor Norte indica que os principais investimentos do Estado e dos capitais serão concentrados neles. Foi levada em conta a localização estratégica dentro de um contexto em que o Aeroporto Internacional Tancredo Neves passará a ser um aeroporto industrial e terá sua capacidade de transporte de passageiros aumentada. Por conseguinte, será o centro de uma organização da produção e circulação de mercadorias, pessoas e de capitais.

No Plano Diretor do município de Confins, por exemplo, leva-se muito em consideração a questão da reestruturação do Vetor Norte, especialmente, pelo fato de 70\% do Aeroporto Industrial Tancredo Neves estar situado dentro de seu território. Quanto a esses aspectos, no seu inciso III, o Plano Diretor do município de Confins versa acerca da intenção do aproveitamento da potencialidade do comércio e dos serviços gerados pelo aeroporto e pela proximidade da rodovia MG-424. Quanto à infraestrutura viária, ressalta o plano a necessidade de "tirar partido" dos projetos governamentais que propõem uma melhor integração rodoviária do aeroporto com a RMBH, envolvendo, principalmente, a futura instalação do "Contorno Rodoviário Norte" de Belo Horizonte (Rodoanel), a ampliação da Linha Verde (MG-010), que liga o centro de Belo Horizonte ao aeroporto de Confins, e 
da rodovia MG-424. A respeito do desenvolvimento do setor industrial, o capítulo II, art. $7^{\circ}$, seção II, desse plano diretor prioriza e incentiva a implantação de uma zona industrial voltada para a produção de tecnologias de ponta, instalações de centros de pesquisa e de atividades de apoio ao complexo industrial, atualmente, em processo de instalação no aeroporto (CONFINS, 1999).

As "vantagens industriais específicas" são, também, de interesse do poder público municipal, sendo incentivada, no artigo VI deste mesmo plano, a propaganda destas vantagens em razão dos projetos oficiais de consolidação do aeroporto como "centro de um processo de desenvolvimento regional" (CONFINS, 1999). O planejamento para o turismo local, também, leva em conta a influência do aeroporto, sendo ressaltado como um compromisso do poder público municipal a elaboração de um plano municipal de desenvolvimento desse setor. Esta influência vai além da representação do aeroporto como espaço de chegada de turistas, estando ligada a pretensa atratividade da capital mineira, Belo Horizonte, pelo denominado "turismo de negócios" (CONFINS, 1999). Evidencia-se como a produção do espaço no Vetor Norte é apropriada pelos governos locais, que se digladiam para receber o almejado retorno econômico advindo da expansão e da ampliação do aeroporto já em curso. Todas essas vantagens econômicas que os Planos Diretores dos municípios do Vetor Norte passaram a buscar despertou a cobiça do capital rentista por ganhos elevados com as rendas fundiárias diferenciais urbanas.

Tendo em vista que, atualmente, grande parte das obras para essa reestruturação promovida pelo Estado já está finalizada, o aeroporto tem sido colocado como um empreendimento norteador da reprodução dos capitais em escala regional, influenciando na produção do espaço, não somente em Confins, mas, também, nos demais municípios do Vetor Norte. A esperança daqueles que creem nos impactos regionais gerados a curto e médio prazos pela ampliação do aeroporto vão no sentido de amenizar a crise de reprodução dos capitais em diversas escalas, devido às novas possibilidades de investimentos de um montante de capitais gerados em diversas partes do mundo e que encontram dificuldades para a exploração de mais trabalho vivo.

De acordo com o documento produzido pela própria Jurong Consultants, o plano para tornar o Vetor Norte uma região mais viável à reprodução dos capitais consiste em torná-la uma aerotropolis ${ }^{13}$, cuja ampliação do Aeroporto Internacional Tancredo Neves seria fundamental para configuração de um corredor multimodal ${ }^{14}$. As outras intervenções a cargo do Estado no espaço do Vetor Norte consistem na requalificação da via MG-010 (doravante Linha Verde), na construção do Centro Administrativo de Minas Gerais (CAMG) e na construção do Rodoanel. O plano, basicamente, consiste na renovação do "capital fixo de tipo independente" (HARVEY, 2013a) da região para garantir competividade aos capitais e aumentar os patamares das rendas fundiárias locais. A aerotropolis pretende ser um atrativo por reduzir o tempo de giro dos capitais, ao reduzir o tempo entre a produção e o consumo das mercadorias.

O planejamento estratégico empregado na produção do espaço do Vetor Norte está conectado com a flexibilização do processo produtivo atuante em escala global e revela o capital tentando lidar com suas crises internas e externas, especialmente a impossibilidade de manter o crescimento econômico, tendo excedentes não aproveitados de capital e de força de trabalho (HARVEY, 2005b, p.134). Ademais, o próprio Harvey (2012, p. 257) aponta que há uma compressão do tempo-espaço

13 As aerotropolis são semelhantes às metrópoles convencionais, entretanto, apresentam uma configuração espacial em que o aeroporto é o centro de uma rede urbana calcada em negócios extremamente interconectados com o aeroporto, constituindo corredores multimodais (JURONG CONSULTANS, 2009, p. 38).

14 Os corredores multimodais "podem ser vistos como uma tentativa deliberada dos governos em associação com universidades e empresas privadas, para planejar e promover a produção tecnologicamente inovadora e a produção industrial dentro de uma ou várias áreas concentradas" (JURONG CONSULTANS, 2009, p. 38). 
no capitalismo pela aceleração do tempo de giro do próprio capital. Nesse contexto atual, em que o processo produtivo se tornou extremamente informatizado e tecnológico e descentralização a produção de mercadorias pode ser gerenciada pelas sedes administrativas das diversas empresas sediadas nas chamadas "cidades globais" como Londres, Nova York, Paris e Tóquio (SASSEN, 1993), que acabam assumindo a função de cidades de negócios e de serviços altamente especializados. Tais empresas globalizadas tentam reduzir a queda tendencial de suas taxas de lucro, explorando o "desenvolvimento geográfico desigual" (HARVEY, 2013b, p. 526) capitalista pelo espaço geográfico, almejando a exploração de trabalhos baratos, a obtenção de vantagens locacionais, a isenção de impostos e outras regalias.

O Vetor Norte está, portanto, inscrito em um planejamento estratégico no qual o próprio estado de Minas Gerais e os municípios, sozinhos ou por meio de parcerias-público-privadas (PPP), tentam inserir seus territórios na divisão internacional do trabalho, criando condições favoráveis para a reprodução dos capitais atuantes em diversas escalas. Em tempos de livre mobilidade geográfica dos excedentes e das unidades produtivas, os municípios atraem as empresas e os capitais, oferecendo facilidades locacionais, redução de impostos e o fornecimento da infraestrutura básica para o escoamento da produção.

Em outros termos, a produção do meio técnico-científico-informacional (SANTOS, 2006, p. 159) no Vetor Norte da RMBH tem como objetivo tornar viável a produção dessas mercadorias, mesmo espacialmente distantes de seus mercados consumidores, pois seu escoamento será viabilizado pelas rotas terrestres e aéreas de comunicação que reestruturadas. Nesse contexto, a criação das condições gerais de produção e a organização estratégica do espaço são estruturais. Para Lefebvre,

\begin{abstract}
a produção do espaço, em si, não é nova. Os grupos dominantes sempre produziram este ou aquele espaço particular, o das cidades antigas, os dos campos (aí incluídas as paisagens que em seguida parecem 'naturais'). O novo é a produção global e total do espaço social. Essa extensão enorme da atividade produtiva realiza-se em função dos interesses dos que a inventam, dos que a gerem, dos que dela se beneficiam (largamente). O capitalismo parece esgotar-se. Ele encontrou um novo alento na conquista do espaço, em termos triviais, na especulação imobiliária, nas grandes obras (dentro e fora das cidades), na compra e na venda do espaço. E isso à escala mundial. Esse é o caminho (imprevisto) da socialização das forças produtivas, da própria produção do espaço. É preciso acrescentar que o capitalismo, visando a sua própria sobrevivência, tomou a iniciativa nesse domínio? A estratégia vai muito mais longe que a simples venda, pedaço por pedaço, do espaço, ela não só faz o espaço entrar na produção da mais-valia, ela visa uma reorganização completa da produção subordinada aos centros de informação e de decisão (LEFEBVRE, 1999, p. 142).
\end{abstract}

Assim, o capital tende a fazer prevalecer o valor de troca das cidades, mostrando o modo como a sua reprodução ampliada engendra seu espaço-tempo, o "espaço abstrato" (LEFEBVRE, 1991).

\title{
Considerações Finais
}

De "obras de arte", como foram as cidades antigas, as cidades modernas vão se tornando capital fixo e fontes de rendas fundiárias, a partir da atuação do urbanismo a cargo do Estado. A questão da renda da terra acaba por determinar, não somente a capitalização das rendas fundiárias por parte do rentista, mas a própria localização das classes sociais no espaço das metrópoles. 0 capital com suas leis, sua moral, seus fins específicos e seu espaço abstrato induzem práticas e arranjos espaciais específicos, ao tornar a cidade uma mercadoria. No capitalismo, o valor enquanto uma relação social expande-se para o ambiente construído das cidades e determina a forma como 
as pessoas vão se relacionar umas com as outras e com seus espaços de vivência. Nesse processo, a práxis social é apropriada para a reprodução do valor. A relação das pessoas com sua cidade e com o espaço social tende a adquirir feições fetichizadas.

Os habitantes das cidades, que também são produtores desses espaços, não mais se reconhecem como tais, pois se veem como produtos. Trata-se de uma desumanização, de uma alienação do e no espaço, pois é uma necessidade do humano a produção e a apropriação do espaço enquanto obra. A modernização das cidades e sua produção de forma padronizada para o mercado, na condição de capital, produzem uma relação distante dos indivíduos com o espaço. É fato que o fetichismo do espaço adquire escalas mais amplas, no entanto, esses processos, com todas as suas contradições, também podem, e devem, gerar o oposto, a politização. Os constantes protestos e revoltas pelo mundo, que têm a cidade como objeto e como objetivo, como os ocorridos no Brasil e na Turquia em 2013 e 2014, são respostas necessárias a essa forma desumana assumida pela materialização dos seres humanos no espaço social, a urbanização capitalista.

Compreender a metropolização e as transformações da e na cidade significa desvendar as determinações da marcha do capital em busca de sua reprodução ampliada e seus desdobramentos para a vida social. Nesse continuo movimento, as distintas espacialidades e sociabilidades da reprodução social vão sendo cada vez mais enclausuradas na cotidianidade das metrópoles e vão adquirindo os ritmos desta. Esses ritmos são os ritmos do trabalho e da produção de mercadorias, entre elas o próprio espaço. A reprodução social nessas áreas agregadas à cotidianidade das metrópoles e do capital globalizado e globalizante tem as suas relações com o tempo e com o espaço alteradas. Os ritmos da produção e da reprodução das mercadorias alcançam um espaço mais amplo. Compreender a metrópole belo-horizontina e a sua reprodução requer uma análise que contemple os desdobramentos do processo de urbanização à vida social. Para Carlos,

\footnotetext{
a metrópole se constitui eliminando os pontos de encontro, o lugar da festa; tragando os rituais e seus mistérios e, com isso, elimina as antigas referências destruindo a memória social e fragmentando o espaço e as relações do indivíduo, por meio da descaracterização decorrente da transformação de bairros inteiros, pelos quais, percebemos as fragmentações no processo de constituição da metrópole (CARLOS, 1999, p. 79).
}

Desde que a urbanização se tornou estrutural para o capital, a vida da e nas cidades foi transformada em vida na e da metrópole. Nesse longo processo, os bairros e as ruas, que eram os locais dos encontros e das festas populares, são transformados para comportar o número crescente de automóveis. No processo de produção da metrópole belo-horizontina é marcante a supressão dos espaços de vivência da classe trabalhadora para viabilizar as reestruturações promovidas pelo Estado, essencialmente no caso das grandes vias de acesso aos centros industriais e aos grandes empreendimentos. Em um momento de grandes transformações com a reestruturação do Eixo Norte da $\mathrm{RMBH}$, o capital e o seu produto, a metrópole, continuam a expandir-se e a reproduzir a sua cotidianidade e sua crise, apropriando-se da práxis social e da vida social nos lugares mais remotos. Para Carlos,

campo da auto-regulação voluntária e planificada, o cotidiano aparece como construção da sociedade, que se organiza segundo uma ordem fortemente burocratizada, preenchida por repressões e coações imperceptíveis no lugar, revelando articulações espaciais mais amplas (o plano do local se acha cada vez mais invadido pelo plano global) (CARLOS, 2001, p. 19).

A capitalização do solo urbano advinda das intervenções do Estado, propiciada por instrumentos de planejamento urbano previstos na legislação urbanística brasileira, tendem a 
dificultar o acesso dos trabalhadores de baixa renda ao espaço urbano. Foi posta em prática mais uma rodada de capitalização do solo urbano, o que tende a promover a gentrificação do espaço da metrópole. Conforme nos diz Marx (2010, p. 80), "o trabalhador se torna tanto mais pobre quanto mais riqueza produz. [...] O trabalhador se torna uma mercadoria tão mais barata quanto mais mercadorias cria". 


\section{Referências}

ALMEIDA, R. P.; MONTE-MÓR, R. L.de M. (2017). Renda da terra e o espaço urbano capitalista contemporâneo. In: Revista de Economia Política, vol. 37, $n^{\circ}$ 2, p. 417-436. Disponível em: http://dx.doi.org/10.1590/0101-31572017v37n02a09 Acesso em: 15 nov. 2020.

ANDRADE, L. T. (2003). "Segregação socioespacial e construção de identidades urbanas". In: MENDONÇA, J. G.; GODINHO, M. H. de L. (org.). População, espaço e gestão na metrópole. Belo Horizonte, Editora PUC Minas.

BELO HORIZONTE. (1942). Relatório dos exercícios de 1940 e 1941, apresentado ao Exmo. Snr. Dr. Benedicto Valladares Ribeiro, Governador do Estado, pelo prefeito Juscelino Kubitschek de Oliveira. Belo Horizonte. Acervo APCBH, Coleção Relatórios anuais de atividades da Prefeitura de Belo Horizonte.

PBH - PREFEITURA MUNICIPAL DE BELO HORIZONTE. (2010). Plano Urbano-Ambiental da Região do Izidoro. Disponível em: https://prefeitura.pbh.gov.br/sites/default/files/estrutura-degoverno/politica-urbana/2018/planejamento-urbano/ouc_plano_urbano_ambiental_isidoro.pdf Acesso em: 05 out. 2016.

BENEVOLO, L. (1983). As origens da urbanística moderna. Portugal: Editora presença, Brasil: Livraria Martins Fontes.

BIHR, A. (2003). A problemática da reprodução do capital em O Capital. Revista Lutas Sociais. São Paulo. n9/10. Disponível em:

http://revistas.pucsp.br/index.php/ls/article/view/25775/18419. Acesso em: 28 fev. 2017.

BOTELHO, A. (2007). O urbano em fragmentos: a produção do espaço e da moradia pelas práticas do setor imobiliário. São Paulo, Annablume/FAPESP.

BRASIL. Lei Complementar No 14, de 8 de Junho de 1973. Estabelece as regiões metropolitanas de São Paulo, Belo Horizonte, Porto Alegre, Recife, Salvador, Curitiba, Belém e Fortaleza.

BRESCIANI, M. S. M. (1992). Londres e Paris no século XIX: o espetáculo da pobreza. Editora Brasiliense. São Paulo, 127 p.

CARLOS, A. F. A. (1999). Apresentando a metrópole na sala de aula. In: Ana Fani Alessandri Carlos. (Org.). A geografia na Sala de aula. $1^{\text {a }}$ ed., São Paulo: Contexto, v. 1, p. 07-134.

CARLOS, A. F. A. (2001). Espaço-Tempo na metrópole: a fragmentação da vida cotidiana. São Paulo: Contexto, 368p.

CASTELLS, M. (1999). A sociedade em rede. São Paulo: Paz e Terra, volume I, 357 p.

CONFINS. (1999). Lei complementar n002/99, de 30 de dezembro de 1999. Plano Diretor Municipal de Confins. Disponível em:

http://www.rmbh.org.br/repositorio/municipios/confins/plano-diretor-de-confins-Ic-n-002 Acessado em: 10 jun. 2014.

COSTA, H. S. M. (1994). Habitação e produção do espaço em Belo Horizonte. In: MONTE-MÓR, R. L. (coord.). Belo Horizonte: espaços e tempos em construção. Belo Horizonte, CEDEPLAR / PBH, p. $51-$ 77.

COSTA, H. S. M. (2006). Mercado imobiliário, Estado e natureza na produção do espaço metropolitano. In: COSTA, H.S.M. et al (orgs). Novas Periferias Metropolitanas: A expansão metropolitana em Belo Horizonte - dinâmica e especificidades no Eixo Sul. Belo Horizonte, Editora C/Arte.

CORRÊA, R. L. (1989). A rede urbana. São Paulo: Editora Ática. 96 p.

ENGELS, F. (2010). A situação da classe trabalhadora na Inglaterra. (Trad. B. A. Schumann; supervisão, apresentação e notas José Paulo Netto). São Paulo: Boitempo, 388 p. 
GOMES, G. C. A. (2012). (re)produção social do espaço de Belo Horizonte e de sua região metropolitana no contexto da modernização urbano-industrial de Minas Gerais. Revista Soc. \& Nat., Uberlândia, ano 24 n² 2, 197-210. Disponível em: http://www.scielo.br/pdf/sn/v24n2/03.pdf . Acesso em: 28 fev. 2017.

HARVEY, D. (2012). A condição pós-moderna. 22ª ed., São Paulo: Edições Loyola.

HARVEY, D. (2005a). Do administrativismo ao empreendedorismo: A transformação da governança urbana no capitalismo tardio. In: HARVEY, D. A produção capitalista do espaço. $2^{a}$ ed., São Paulo, Annablume.

HARVEY, D. (2005b). A Geopolítica do capitalismo. In: HARVEY, D. A produção capitalista do espaço. $2^{a}$ ed., São Paulo, Annablume.

HARVEY, D. (2013a). Os limites do Capital. Trad. Magda Lopes. $1^{\text {a }}$ ed., São Paulo. Boitempo.

HARVEY, D. (2013b). O novo imperialismo. Tradução: Adail Sobral, Maria Stela Gonçalves. São Paulo, $7^{\text {a }}$ Ed., Edições Loyola.

HARVEY, D. (2015). Paris, capital da modernidade. Trad. Magda Lopes. $1^{\text {a }}$ ed., Boitempo.

HARVEY, D. (2019). Teoria da crise e a queda da taxa de lucro. In: Revista Geografares: Espírito Santo, $n^{\circ} 28$, p. 15-35.

HISSA, C. E. V. (1997). O projeto de pesquisa: valores e contextos. Caderno de Geografia. Belo Horizonte: Pontifícia Universidade Católica de Minas Gerais, v. 7, n.9, p. 39-55.

HOBSBAWM, E. (1979). A era do capital: 1848-1875. $2^{\text {a }}$ ed., Rio de Janeiro, Editora Paz e Terra.

JARAMILLO, S. (2010). Hacia uma teoria de la renta del suelo urbano. Universidad de los Andes: Bogotá, $2^{\mathrm{a}}$ ed, $472 \mathrm{p}$.

JARAMILLO, S. (2013). Acerca de la investigación en mercados de tierra urbana en América Latina. In:

CEDE-Universidad de los Andes, Bogotá, Vol. 22. Disponível em: https://ideas.repec.org/p/col/000089/010736.html Acesso em: 10/01/2018.

JORNAL ESTADO DE MINAS ONLINE. (19 abr. 2010). Vetor Norte da Grande BH projeta investimentos. Disponível em:

https://www.em.com.br/app/noticia/economia/2010/04/19/internas_economia,156206/vetornorte-da-grande-bh-projeta-investimentos.shtml Acesso em: 19 abr. 2014.

JURONG CONSULTANTS. (2009). Strategic Framework Report: Belo Horizonte Multi-Modal Corridor. 2009. Disponível em: http://www.globalurban.org/MG/2\%20\%20Relatrio\%20da\%20Estrutura\%20Estratgica\%20-\%20Frost\%20\&\%20Sullivan.pdf

Acesso em: 20 jun. 2014.

KOWARICK, L. (2000). Escritos Urbanos. São Paulo: Condições Sociais. Ed 34, 144p.

LEFEBVRE, H. (1999). A revolução urbana. Belo Horizonte: Editora UFMG.

LEFEBVRE, H. (2016). Espaço e política: O direito à cidade II. MARTINS, S.; ANDRADE, M. (Trad.). $2^{a}$ ed. Belo Horizonte, Editora UFMG.

LEFEBVRE, H. (1991). The production of space. $3^{\text {a }}$ ed., Oxford, Blackwell.

MARTINS, S. M. M. (2000). O urbanismo, esse (des)conhecido saber político. Revista Brasileira de Estudos Urbanos e Regionais (ANPUR), $n^{\circ}$ 3, Recife, p. 39-59. Disponível em: < http://unuhospedagem.com.br/revista/rbeur/index.php/rbeur/article/view/45/31> . Acesso em: 20 fev. 2017.

MARTINS, S. M. M. (2001). Rentismo e autoritarismo: fundamentos seculares de uma metrópole anticidadã. In: Spósito, M. E. B. (org.). Urbanização e cidades: Perspectivas geográficas. Presidente Prudente. UNESP.

MARTINS, S. M. M.; GOMES, G. C. (2009). A verdade que está no erro: a importância do Estatuto da Cidade para a (re)valorização do espaço. Revista da ANPEGE, v. 5, p. 123-139. 
MARX, K. (2010). Manuscritos econômico-filosóficos. Tradução Jesus Ranieri. 4ª reimpr, São Paulo, Boitempo.

MARX, K. (2011). O Capital: crítica da economia política. Livro I. Civilização Brasileira: Rio de janeiro, $29^{\mathrm{a}}$ ed, $929 \mathrm{p}$.

MENDONÇA, S. R. (2012). Estado e Economia no Brasil: opções de desenvolvimento. 4ª ed. Rio de Janeiro: Paz e Terra.

MENDONÇA, J. G.; COSTA, H. S. M. (2003). Entre a homogeneização e a diversidade: segregação sócio-espacial na metrópole belo-horizontina e as especificidades do eixo sul. Espaço e Debate, v. 24, n. 45, p. 75-86.

MONBEIG, P. (1957). Novos Estudos de Geografia Humana Brasileira. São Paulo: Difusão Européia do Livro.

MONTE-MÓR, R. L. M. (1994). Belo Horizonte: a cidade planejada e a metrópole em construção. In: Belo Horizonte: espaços e tempos em construção. MONTE-MÓR, R. L. de M. (coord.). Belo Horizonte, CEDEPLAR / PBH, p. 12-27.

OLIVEIRA, F. (1977). Acumulação monopolista, Estado e Urbanização: a nova qualidade do conflito de classes. In: Moisés, J. A. et al. (orgs) Contradições urbanas e movimentos sociais. Rio de Janeiro, Editora Paz e Terra, p. 65-76.

ROLNIK, R.; SOMEKH, N. (2003). Governar as metrópoles: Dilemas da recentralização. In: GONÇALVES, M. F.; BRANDÃO, C. A.; GALVÃO, A. C. (org.) Regiões e cidades, cidades nas regiões. 0 desafio urbano-regional. São Paulo, UNESP, ANPUR, p. 95-104.

SALGUEIRO, H. A. (1997). Engenheiro Aarão Reis: o progresso como missão. Belo Horizonte: Sistema Estadual de Planejamento, Fundação João Pinheiro, Centro de Estudos Históricos e Culturais.

SANTOS, M. (2012). A Natureza do Espaço: Técnica e Tempo, Razão e Emoção. São Paulo, Editora da Universidade de São Paulo [4. ed. 7. reimpr.].

SANTOS, M.; SILVEIRA, M. L. (2006). O Brasil: território e sociedade no início do século XXI. 9ª ed., Rio de Janeiro, Editora Record.

SASSEN, S. (1993). A cidade global. In: LAVINAS, L., CARLEIAL, L. \& NABUCO, M. (orgs.). Reestruturação do espaço urbano e regional no Brasil. São Paulo, Anpur/Hucitec.

SMITH, N. (2007). Gentrificação, a fronteira e a reestruturação do espaço urbano. SANFELICI, D. M. (Trad.) Revista GEOUSP - Espaço e Tempo. São Paulo, n²1, p. 15-31. Disponível em:

http://www.geografia.fflch.usp.br/publicacoes/Geousp/Geousp21/Artigo_Neil.pdf

Acesso em: 15 out. 2016.

SOUZA, J.; BRITO, F. (2008). A expansão urbana de Belo Horizonte e da Região Metropolitana de BH em direção ao Vetor Norte Central. In: XVI Encontro da ABEP, Caxambu. Anais do XVI Encontro da ABEP. Disponível em: https://diamantina.cedeplar.ufmg.br/portal/download/diamantina2008/D08A011.pdf Acesso em: 20 out. 2018.

TOPALOV, C. (1979). La urbanization capitalista: alguns elementos para su análisis. México, editorial Edicol.

VEDROSSI, A. O.; MONETTI, E. (2002). A securitização de recebíveis imobiliários: uma alternativa de aporte de capitais para empreendimentos residenciais no Brasil. In: Boletim Técnico da Escola Politécnica da USP. São Paulo: EPUSP, 20 p. Disponível em: http://antac.pcc.usp.br/files/text/publications/BT_00326.pdf Acesso em: 12 mar. 2017. 